\title{
HORIZONTAL ALVEOLAR RIDGE AUGMENTATION WITH AUTOGENOUS BLOCK BONE GRAFT A CONE BEAM COMPUTED TOMOGRAPHY EVALUATION CASE SERIES
}

\author{
Alaa Talaat Ali*, Nevine Hassan Kheir El Din ${ }^{* *}$ and Ahmed El Sayed Hamed Amr ***
}

\begin{abstract}
Objective: The aim of the present study was to evaluate horizontal alveolar ridge augmentation using autogenous block grafts harvested from mandibular symphysis without barrier membrane in severe maxillary anterior ridge defects.

Materials and methods: Six healthy patients with horizontal defects of the maxillary alveolar ridges were selected for alveolar ridge augmentation (class IV atrophy according to Benic and Hammerle classification). These defects were treated by autogenous block onlay grafts harvested from mandibular symphysis protected by anorganic bovine bone particles only. Bone width was assessed preoperative, immediately post-operative and after 6 months at re-entry by cone beam computed tomography.
\end{abstract}

Result: All block grafts sites provided sufficient ridge width for proper implant placement. Mean bone gain was $3.9 \mathrm{~mm}$. No soft tissue dehiscence occurred in any of the cases.

Conclusion: A combination of autogenous block graft obtained from the symphysis, combined with particulates xenograft alone without barrier membrane is a predictable and successful technique for augmenting maxillary horizontal ridge deficiency.

KEYWORDS: ridge augmentation, block graft, symphysis bone block

\section{INTRODUCTION}

Bone loss after a tooth extraction is often dramatic, inevitable and is particularly noticeable in the first year. Bone resorption patterns could be vertical or horizontal, that making implant placement in the right position is challenging (Levin et al., 2007). The deficient alveolar ridge always presents many challenges to clinicians

\footnotetext{
*Assistant Lecturer of Oral Medicine, Periodontology and Oral Diagnosis Faculty of Dentistry, Assiut University ** Professor of Oral Medicine, Periodontology and Oral Diagnosis, Faculty of Dentistry, Ain Shams University *** Assistant Professor of Oral Medicine, Periodontology and Oral Diagnosis, Faculty of Dentistry, Ain Shams University
} 
(Seibert \& Cohen., 1987) With the arise of implant therapy and increased esthetic and functional demands from the patients, resorbed alveolar ridge repair has become a crucial prerequisite for implant insertion and survival, and hence necessitates both hard and soft tissue reconstruction (Pikos., 2005).

In one of the most often cited preclinical studies on the topic, Araújo and Lindhe found that within an 8 -week healing period following a tooth extraction, there was a significant loss of ridge dimension, particularly on the thin buccal wall due to being made entirely of bundle bone, and therefore modeling resulted in tremendous vertical resorption of the buccal crest (Araújo et al.,2005). The alveolar ridge width was reduced by $50 \%$ during the observation period of 1 year, which is in agreement with earlier studies (Johnson, 1969). Approximately two-thirds of the alveolar bone loss occurred during the first 3 months (Dye et al., 2015).

Different techniques have been applied for bone augmentation before implant placement such as guided bone regeneration (GBR) with particulate bone materials, alveolar ridge splitting, screw tent pol, and distraction osteogenesis and have shown some promising results.(González-García et al., 2011) .Nevertheless, block grafting has been considered to be the most predictable approach for extensive or severely atrophic ridges (Maiorana et al 2005; Monje et al., 2014).

Harvesting Autogenous bone block can be performed from different locations; intraoral bone block grafts from mandibular symphysis and ramus buccal shelf while extraoral from calvaria or the iliac crest, (Albrektsson and Johansson, 2001a). For alveolar ridge augmentation, intraoral donor sites such as the mandibular symphysis and buccal shelf of ramus are excellent intraoral sources for obtaining a cortico-cancellous or pure cortical bone block, respectively. Furthermore, bone blocks harvested from intramembranous mechanism (intraoral) sites revascularize faster than those taken from an endochondral (extraoral) derived formation pathway (Lekholm et al., 1999). The mandibular symphysis has been shown to generate enough bone to enhance a deficient ridge by $4-6 \mathrm{~mm}$ horizontally and up to $4 \mathrm{~mm}$ vertically, covering a 3 -tooth deficit. The typical bone block size obtainable from this area is $10 \mathrm{~mm}$ in height, $15 \mathrm{~mm}$ in width, and 6 $\mathrm{mm}$ in thickness, with an average bone volume of roughly $860 \mathrm{~mm}$.

The symphyseal bone block is contraindicated when the donor site does not have a 3-5mm "safety zone" around the mental nerves, lower border, and incisor apices (following the rule of 5). Also, there are some disadvantages as post-operative morbidity which was reported after symphysis grafting. Misch reported that 10.7 percent of patients experienced incision dehiscence at the donor site, 9.6 percent experienced temporary paresthesia that lasted up to 6 months, and 29 percent had altered lower incisor sensation after undergoing a symphyseal bone block harvesting (Misch, 1997).

Autogenous block Graft resorption has clinical relevance since it could interfere with the outcome of the reconstruction. Its rate during healing is affected by a variety of factors, the most important of them being the stability of the graft, the origin of the bone used for grafting in terms of endochondral versus intramembranous ossification, the type of bone that used for grafting in terms of cortical versus corticocancellous( Cordaro, 2014). In the absence of complications, various authors have reported average amounts of autogenous bone block resorption ranging from 20 percent to 50 percent, depending on the study (Chiapasco et al., 2006a). This is not a big clinical problem if the defect can be readily overbuilt or over contoured( Cordaro and Terheyden, 2014).

A common approach to preventing premature autogenous block graft resorption is to incorporate bone blocks with various bone substitutes or/and barrier membranes, Both of which have shown to reduce or even eliminate resorption of bone block grafts also a randomized trial has substantiated 
the positive effect of barrier membranes against bone resorption (Antoun et al., 2001; Cordaro et al., 2011; Wiltfang et al., 2014). But it is useful to remember that soft tissue dehiscence and graft exposure may occur more frequently in the presence of a membrane, regardless of non-resorbable or resorbable, also its effect on reducing surface resorption of the autogenous bone block is debatable (Maiorana et al., 2005; Von Arx and Buser, 2006).

The aim of the present study was to evaluate horizontal alveolar ridge augmentation using autogenous block grafts harvested from mandibular symphysis without barrier membrane in severe maxillary anterior ridge defects using cone-beam computed tomography (CBCT).

\section{SUBJECTS AND METHODS}

\section{Patient selection:}

Six patients were referred from the outpatient clinic of the Department of Oral Diagnosis, Oral medicine \& Periodontology, Faculty of Dentistry, Ain Shams University. All the patients received written detailed information about the study nature and treatment protocol, an informed consent form was signed by all the patients.

\section{Inclusion criteria:}

- All patients had partially edentulous ridge (missing maxillary one or two neighboring anterior teeth), class IV atrophy according to Benic and Hammerel classification (Benic and Hammerle, 2014).

- Able to maintain good oral hygiene, medically free according to Burket health medical history questionnaire (Glick et al.2008).

- Age range 20-50 years.

- Adequate alveolar ridge height.

- Healthy mandibular symphysis as a bone donor site.

\section{Exclusion criteria:}

Pregnant, smokers, or taking medications or suffering from systemic diseases or conditions known to affect the metabolism of bone.

\section{Surgical procedures}

Harvesting technique of the symphyseal bone block graft from the donor site

The Surgical technique was executed as described by Misch et al.,1992. Under local anesthesia, a submarginal incision was made on the attached gingiva in the donor site. A full-thickness flap was elevated, exposing the mandibular symphysis. With respecting the rule of 5, The outline for a symphysis block graft was located $5 \mathrm{~mm}$ above the inferior border of the mandible, $5 \mathrm{~mm}$ away from the mental foramina, and $5 \mathrm{~mm}$ away from the root apices of anterior teeth. Rectangular block grafts were harvested using a piezo-electric device (Acteon piezotome, Satelec, France) and chisel and mallet were used to separate the graft. Sharp edges around the blocks were then smoothed out with a large round bur.the flaps were closed with a single interrupted suture (5-0 polypropylene blue monofilament suture, Assut, Swiss).

\section{Recipient site preparation}

A midcrestal incision was created at the recipient site, followed by intrasulcular and vertical releasing incisions, after which a full-thickness flap was reflected in the donor site. Decortication of the cortical bone on the labial aspect of the recipient site was performed Fig (1). The bone block graft was adapted to the recipient sites and fixated to the residual ridge by 1 or 2 titanium fixation screws 1.5 $\mathrm{mm}$ in diameter Fig (2). A particulate xenograft of bovine origin was packed around the block graft and the ridge to fill any spaces. Finally, the buccal flap was severed by periosteal releasing incision to guarantee flap closure without tension, and the flaps were sutured with a horizontal mattress suture and single interrupted suture (5-0 polypropylene blue monofilament suture, Assut, Swiss). 


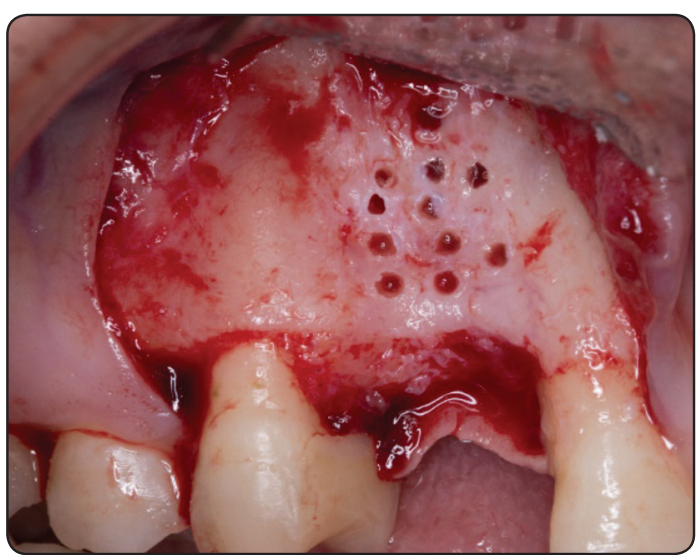

Fig. (1) decortication of the labial bone

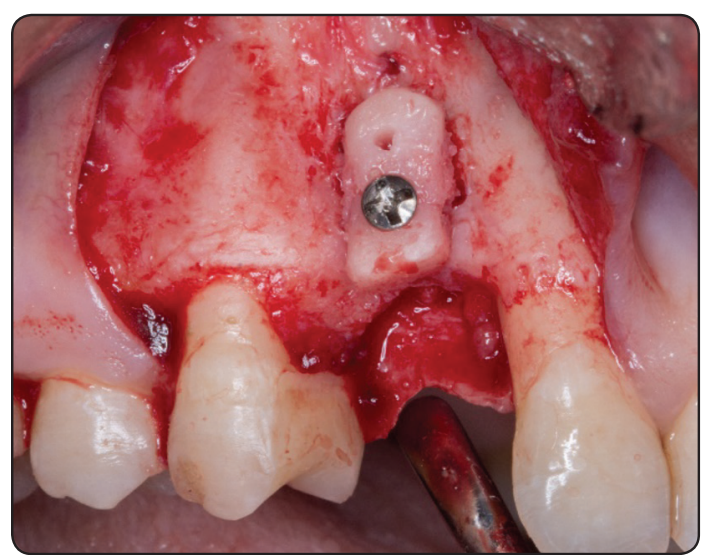

Fig. (2) fixation of bone block graft

\section{Radiographical evaluation}

Cone Beam Computed Tomography (CBCT) measurements of the alveolar ridge were carried out on three occasions: Baseline CBCT was performed one week before the ridge augmentation surgery. The second CBCT was performed immediately post-operative, the third CBCT was performed before implant surgery. In the $\mathrm{CBCT}$, measurements of the edentulous area were made on 3 sagittal views. At each sagittal view, measurements were made at 3 different levels of the ridge ( 3 horizontal lines recorded bone width at the crest, 3 , and $6 \mathrm{~mm}$ from the crest). Thus 9 measures for the ridge labiopalatal width for each patient were made on a single occasion then the mean labio-palatal width was calculated (figure 3 ).

\section{Statistical Analysis}

Values were presented as mean, standard deviation (SD), confidence intervals, median and range values. Data were explored for normality using Kolmogorov-Smirnov test of normality. The results of Kolmogorov-Smirnov test indicated that bone width data were normally distributed (parametric data), therefore paired t-test was used for pairwise comparison between observation times. Difference and percent change in bone width were non-parametric data, therefore Wilcoxon signed Rank test was used for pairwise comparison between intervals. The significance level was set at $p \leq 0.05$. Statistical analysis was performed with SPSS 18.0 (Statistical Package for Scientific Studies, SPSS, Inc., Chicago, IL, USA) for Windows.

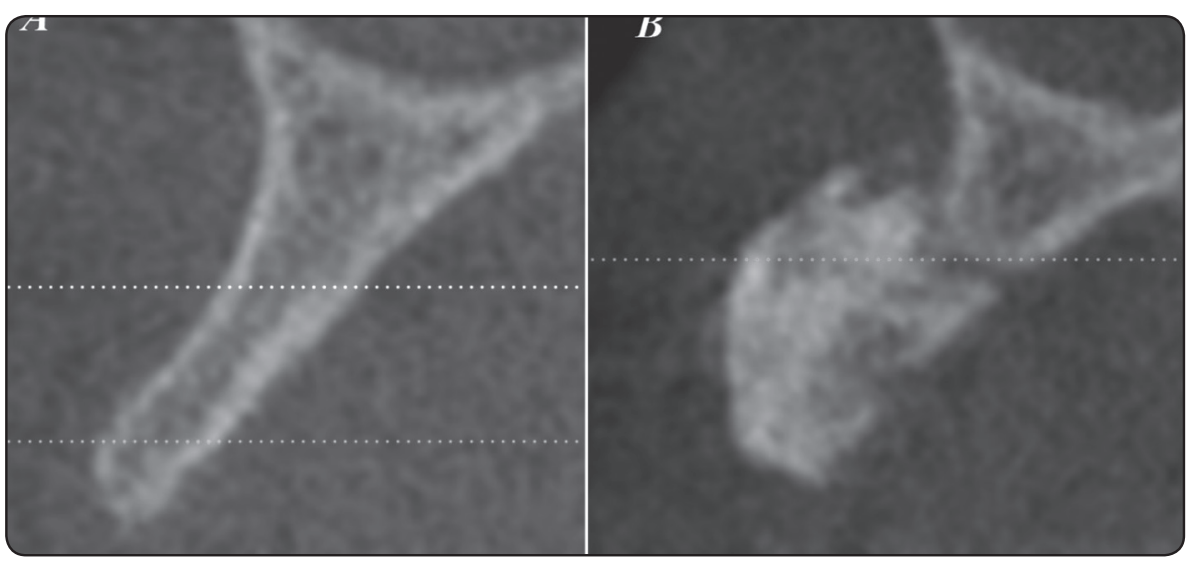

Fig. (3) showing: (A) Sagittal cross-section of the measured ridge taken prior to bone grafting surgery using a conebeam computed tomography (CBCT). (B) Sagittal crosssection of the measured ridge before implant placement (6 months after the grafting surgery) obtained using CBCT. 


\section{RESULTS}

Six patients were enrolled in this study. Six onlay block grafts were harvested from the mandibular symphysis. In all patients wound healing was uneventful, without any reported soft tissue dehiscence and graft exposure. Temporary neurosensory disturbances after bone block harvesting were reported in three chin harvesting sites with a complete resolution between 2 weeks and 1 month.

\section{A- Changes by time in bone width ( $\mathrm{mm}$ )}

The mean bone width at baseline was 5.08土.8 . the mean value showed a statistically significant increase $(\mathrm{p}=0.00)$, to reach a mean $(9.83 \pm 1.04)$ Immediately post-operative. This was followed by a significant decrease $(\mathrm{p}=0.008)$ after 6 months to reach a mean $(9.05 \pm 1.14)$. Comparing the mean value at baseline and after 6 months revealed a statistically significant difference (increase) $(\mathrm{p}=0.00)$, (Table 1, Fig.4)

\section{B-Difference in Bone Width (mm)}

The mean difference in bone width from baseline to immediately post-operative was $4.75 \pm 1.03$; while the mean value of difference from immediately postoperative to after 6 months was $(0.78 \pm .44)$. The difference between both intervals was statistically significant $(\mathrm{p}=0.027)$. Overall (from baseline to after 6 months), the mean difference in bone width was (3.97 \pm 1.21$)$. (Table 2, Fig.4)

TABLE (1) Descriptive statistics of bone width at baseline, Immediately post-operative and after 6 months

\begin{tabular}{|c|c|c|c|c|c|c|c|c|c|c|}
\hline & \multirow[t]{2}{*}{ Mean } & \multirow[t]{2}{*}{ SD Dev } & \multicolumn{2}{|c|}{$\begin{array}{l}\text { 95\% Confidence } \\
\text { interval }\end{array}$} & \multirow[t]{2}{*}{$\begin{array}{c}\text { Mean } \\
\text { difference }\end{array}$} & \multicolumn{2}{|c|}{$\begin{array}{l}95 \% \text { Confidence } \\
\text { interval of mean } \\
\text { difference }\end{array}$} & \multirow[t]{2}{*}{$\begin{array}{c}\text { Baseline } \\
\text { versus } \\
\text { immediate } \\
\text { post-operative }\end{array}$} & \multirow[t]{2}{*}{$\begin{array}{l}\text { Immediate } \\
\text { post-operative } \\
\text { versus after } \\
6 \text { months }\end{array}$} & \multirow[t]{2}{*}{$\begin{array}{c}\text { Baseline } \\
\text { versus after } \\
6 \text { months- }\end{array}$} \\
\hline & & & Lower & Upper & & Lower & Upper & & & \\
\hline Baseline & 5.08 & .80 & 4.24 & 5.93 & & & & & & \\
\hline $\begin{array}{c}\text { Immediately post- } \\
\text { operative }\end{array}$ & 9.83 & 1.04 & 8.74 & 10.93 & & & & & & \\
\hline After 6 months & 9.05 & 1.14 & 7.85 & 10.25 & & & & & & \\
\hline $\begin{array}{c}\text { Baseline- } \\
\text { Immediately post- } \\
\text { operative }\end{array}$ & & & & & 4.75 & 3.67 & 5.83 & & & \\
\hline $\begin{array}{c}\text { Immediately } \\
\text { post-operative- After } \\
6 \text { months }\end{array}$ & & & & & -.78 & -1.25 & -.32 & & & \\
\hline $\begin{array}{c}\text { Baseline- After } 6 \\
\text { months }\end{array}$ & & & & & 3.97 & 2.70 & 5.24 & & & \\
\hline$t$ value & & & & & & & & -11.26 & 4.32 & -8.02 \\
\hline Pvalue & & & & & & & & $.000^{*}$ & $.008 *$ & $.000^{*}$ \\
\hline
\end{tabular}

Significance level $P \leq 0.05$, *significant 
TABLE (2A) Descriptive statistics of difference in bone width at baseline, immediately postoperative and after 6 months

\begin{tabular}{|l|c|c|c|}
\hline \multirow{2}{*}{} & \multirow{2}{*}{ Median } & \multicolumn{2}{|c|}{ Range } \\
\cline { 3 - 4 } & & Min & Max \\
\hline $\begin{array}{l}\text { Baseline- Immediately } \\
\text { post-operative }\end{array}$ & 4.60 & 3.30 & 6.50 \\
\hline $\begin{array}{l}\text { Immediately post- } \\
\text { operative- After 6 months }\end{array}$ & -.85 & -1.40 & -.10 \\
\hline Baseline- After 6 months & 4.10 & 1.90 & 5.50 \\
\hline
\end{tabular}

TABLE (2B) Pairwise comparison of difference in bone width at baseline, immediately postoperative and after 6 months (Wilcoxon signed Rank test)

\begin{tabular}{|l|l|l|l|}
\hline & $\begin{array}{l}\text { Baseline to } \\
\text { immediate } \\
\text { post-operative } \\
\text { versus } \\
\text { immediate } \\
\text { post-operative } \\
\text { versus after } \\
6 \text { months }\end{array}$ & $\begin{array}{l}\text { Immediate } \\
\text { post-operative } \\
\text { to after 6 } \\
\text { months versus } \\
\text { Baseline to } \\
\text { after 6 months }\end{array}$ & $\begin{array}{l}\text { Baseline to } \\
\text { immediate } \\
\text { post-operative } \\
\text { versus Baseline } \\
\text { to after } \\
6 \text { months }\end{array}$ \\
\hline $\mathrm{Z}$ value & -2.214 & -2.207 & -2.201 \\
\hline $\mathrm{P}$ value & $.027^{*}$ & $.027^{*}$ & $.028^{*}$ \\
\hline
\end{tabular}

\section{Significance level P $\leq 0.05$, *significant}

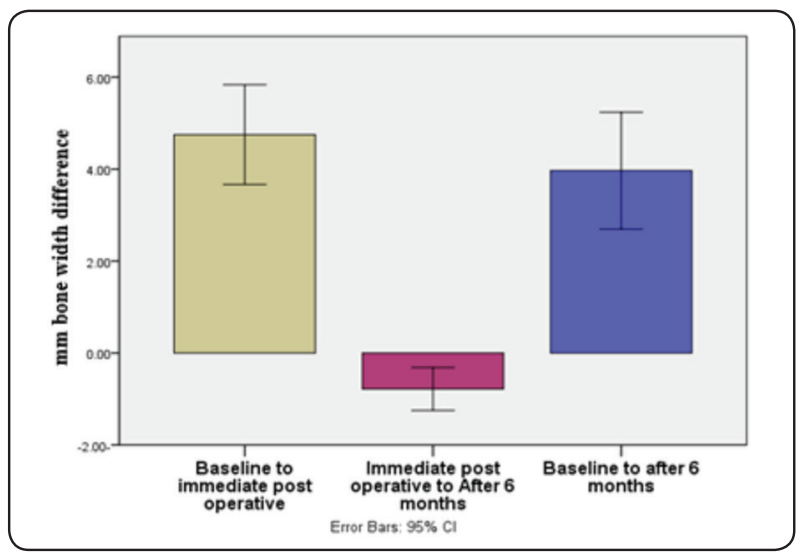

Fig. (4) Bar chart illustrating $\mathrm{mm}$ bone width difference in different intervals

\section{Percent change in Bone Width (\%)}

The mean percent change in bone width from baseline to immediately post-operative was $96.23 \pm 26.99$; while the mean value of percent change from immediately post-operative to after 6 months was $(-8.05 \pm 4.58)$. The difference between both intervals was statistically significant $(\mathrm{p}=0.028)$. Overall (from baseline to after 6 months), the mean percent change in bone width was $(80.78 \pm 28.26)$. (Table 3, Fig.5)

TABLE (3A) Descriptive statistics of percent change in bone width at baseline, immediately postoperative and after 6 months

\begin{tabular}{|l|l|l|l|}
\hline \multirow{2}{*}{} & \multirow{2}{*}{ Median } & \multicolumn{2}{|c|}{ Range } \\
\cline { 3 - 4 } & & Min & Max \\
\hline $\begin{array}{l}\text { Baseline- Immediately post- } \\
\text { operative }\end{array}$ & 98.94 & 53.23 & 125.00 \\
\hline $\begin{array}{l}\text { Immediately post-operative- } \\
\text { After 6 months }\end{array}$ & -8.72 & -14.74 & -.96 \\
\hline Baseline- After 6 months & 80.47 & 30.65 & 109.76 \\
\hline
\end{tabular}

TABLE (3B) Pairwise comparison of percent change in bone width at baseline, immediately post-operative and after 6 months (Wilcoxon signed Rank test)

\begin{tabular}{|l|l|l|l|}
\hline & $\begin{array}{l}\text { Baseline to } \\
\text { immediate } \\
\text { post-operative } \\
\text { versus } \\
\text { immediate } \\
\text { post-operative } \\
\text { versus after } 6 \\
\text { months }\end{array}$ & $\begin{array}{l}\text { Immediate } \\
\text { post-operative } \\
\text { to after 6 } \\
\text { months versus } \\
\text { Baseline to } \\
\text { after 6 months }\end{array}$ & $\begin{array}{l}\text { Baseline to } \\
\text { immediate } \\
\text { post-operative } \\
\text { versus } \\
\text { Baseline to } \\
\text { after 6 months }\end{array}$ \\
\hline $\mathrm{Z}$ value & -2.201 & -2.201 & -2.201 \\
\hline $\mathrm{P}$ value & $.028 *$ & $.028 *$ & $.028 *$ \\
\hline
\end{tabular}

Significance level P $\leq 0.05$, *significant 


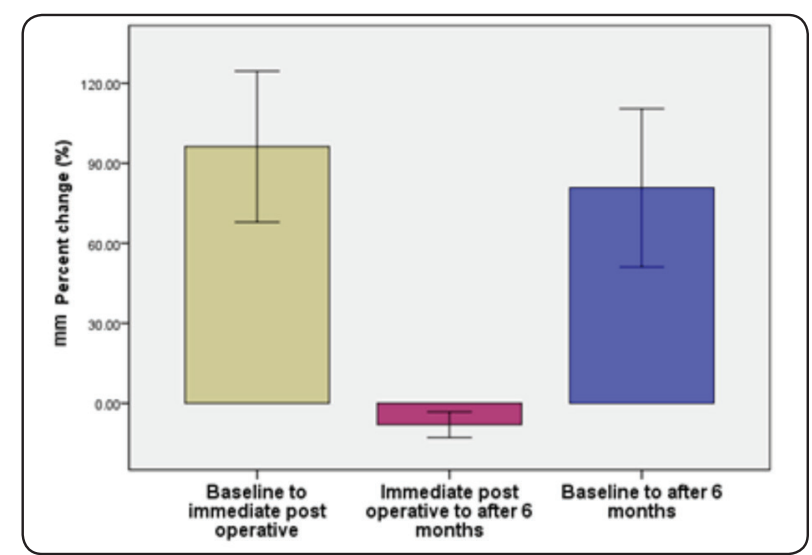

Fig. (5) Bar chart illustrating mm percent change in bone width different intervals

\section{DISCUSSION}

A sufficient amount of bone is required for predictable osseointegration of dental implants as well as for satisfactory aesthetics. Several techniques have been described for the reconstruction of maxillary atrophic ridge defects. One of which is the autogenous bone grafting technique that results in highly successful and predictable outcomes compared with other horizontal ridge augmentation approaches(Albrektsson and Johansson, 2001; Jensen and Terheyden., 2009; Miron et al., 2011; Monje et al., 2014).

All patients in the present study were medically free to decrease the variables and to prevent any factors that might affect healing(Moy and Aghaloo, 2019). Also, all patients in the present study were non-smokers, as smoking has a negative effect on wound healing, bone augmentation and dental implants success rate(Zhao et al., 2018).

In the present study, autogenous block graft was selected due to its biological properties which are osteoconductive, osteoinductive, and osteogenic, In addition, the absence of immunological reactions. Moreover, the autogenous bone graft is considered the gold standard for bone reconstruction procedures harvested from symphysis(Chiapasco et al., 2007).

The selection of the symphysis as a donor site was based on the easy accessibility to the surgical site compared to the mandibular ramus. In addition, the symphysis bock grafts were larger in volume than the ramus block graft ( Misch, 1997).

In our study, anorganic bovine bone(ABB) particles were added to fill the voids between the block graft and recipient bed to reduce bone graft resorption, avoid interference with vascularization of the graft and formation of fibrous tissue ingrowth between the recipient bed and the block graft. Moreover, ABB particles have osteoconductive properties and offering a low substitution rate, which resulted in less graft resorption six months after the procedure as demonstrated in many previous studies (Von Arx and Buser 2006; Cordaro et al., 2011).

In the present study, the perforations into underlying marrow in the recipient site were performed using a $1 \mathrm{~mm}$ round bur to accelerate revascularization of block graft from bone marrow vasculature (Misch et al 1992).

In the present study, the bone block grafts were not covered by a membrane, in literature, the effect of barrier membranes on Autogenous bone block grafts is heterogeneous. According to Hämmerle and Lang., 2001, placing a membrane over the graft sites may help to exclude unwanted cells from the wound, protect the wound, and, as a result, promote bone regeneration. However, when block graft was used as the graft material, no difference was found between the sites treated with and without membrane from a histologic and immunohistochemically standpoint when the sites were treated with or without membrane (Donos et al., 2002; Adeyemo et al., 2008; Gielkens et al., 2008). The purpose of this study was not to demonstrate the effectiveness of placing a barrier membrane or its influence on bone resorption. However, when comparing the results of our study to those of previous studies, we discovered that the addition of $\mathrm{ABB}$ particles resulted in more successful implant placement outcomes. Where a combination of ABB and barrier membrane was applied. (Chappuis et al., 2017; Elnayef et al., 2018; Maiorana et al., 2020). 
In our study, the osteotomy of bone block graft was performed by a piezoelectric surgical device. In literature, there are several studies showing evidence of histomorphological bone heat osteonecrosis utilizing conventional methods as rotary instruments, while piezoelectric surgery does not ( Rullo et al., 2013; Pereira et al., 2014). In addition, Block detachment requires much less force than is necessary when using a rotary instrument. Though, slow cutting rates and increased surgical time may be a disadvantage of piezoelectrical instruments(Sohn et al., 2007).

According to the result of this study, it revealed that mandibular symphysis block grafts in combination with ABBM alone are a predictable approach for augmenting severely reabsorbed maxillary horizontal deficient ridges. Mean bone gain was $3.9 \mathrm{~mm}$ when assessed by CBCT. All implants were successfully placed in all cases. this result was in accordance with a systematic review published by Sanz-Sánchez et al reported that mean bone gain for block graft techniques was $3.5 \mathrm{~mm}$ (Sanz-Sánchez et al., 2015).

Regarding radiographic bone width, there was a statistically significant increase in bone width from baseline to six months, These results were in agreement with those published by (Levin et al., 2007; Mendoza-Azpur et al., 2019; Zaki et al., 2017). Regarding radiographic percentage changes in bone width from baseline to after 6 months revealed that the mean percent change in bone width was $(80.78 \pm 28.26)$ these results were in accordance with (Zaki et al., 2017).

Regarding postoperative complications in the present study, neither soft tissue dehiscence nor block graft exposure occurred at any stage for all the patients. After mandibular bone harvesting procedures, it has been reported that postoperative morbidity is primarily related to temporary or permanent neural disturbances involving the inferior alveolar nerve and its branches. (Chiapasco et al., 2006b).in the present study, neural disturbances were temporary from 2 weeks to 2 months and completely resolved, this was also reported by many previous studies in the literature(Misch, 1997; Esen et al.,2015; Mendoza-Azpur et al.,2019; Maiorana et al., 2020).

The potential concerns in this study are the small sample size and short study period; hence, future studies with a larger sample size and a longer follow-up period are required to confirm the findings reported in this study.

\section{CONCLUSION}

Within the limitations of the present study, a combination of block graft harvested from the mandibular symphysis, combined with particulate xenograft alone without a barrier membrane is a predictable approach in augmenting anterior maxillary horizontal ridge deficiency.

\section{ABBREVIATIONS}

ABB: Anorganic bovine bone, CBCT: Cone Beam Computed Tomography

\section{REFERENCES}

- Adeyemo, W. L., Reuther, T., Bloch, W., Korkmaz, Y., Fischer, J. H., Zöller, J. E., \& Kuebler, A. C. (2008). Healing of onlay mandibular bone grafts covered with collagen membrane or bovine bone substitutes: A microscopical and immunohistochemical study in the sheep. International Journal of Oral and Maxillofacial Surgery, 37(7), 651-659.

- Albrektsson, T., \& Johansson, C. (2001a). Osteoinduction, osteoconduction and osseointegration. European Spine Journal, 10, S96-S101.

- Albrektsson, T., \& Johansson, C. (2001b). Osteoinduction, osteoconduction and osseointegration. European Spine Journal, 10(Suppl 2), S96-S101.

- $\quad$ Antoun, H., Sitbon, J. M., Martinez, H., \& Missika, P. (2001). A prospective randomized study comparing two techniques of bone augmentation: Onlay graft alone or associated with a membrane. Clinical Oral Implants Research, 12(6), 632-639. 
- $\quad$ Araújo, M. G., Sukekava, F., Wennström, J. L., \& Lindhe, J. (2005). Ridge alterations following implant placement in fresh extraction sockets: An experimental study in the dog. Journal of Clinical Periodontology, 32(6), 645-652.

- Chappuis, V., Cavusoglu, Y., Buser, D., \& Arx, T. Von. (2016). Lateral Ridge Augmentation Using Autogenous Block Grafts and Guided Bone Regeneration : A 10-Year Prospective Case Series Study. 19(1), 85-96.

- Chiapasco, M., Zaniboni, M., \& Boisco, M. (2006a). Augmentation procedures for the rehabilitation of deficient edentulous ridges with oral implants. Clinical Oral Implants Research, 17(SUPPL. 2), 136-159.

- Chiapasco, M., Zaniboni, M., \& Boisco, M. (2006b). Augmentation procedures for the rehabilitation of deficient edentulous ridges with oral implants. Clinical Oral Implants Research, 17(SUPPL. 2), 136-159.

- Chiapasco, M., Zaniboni, M., \& Rimondini, L. (2007). Autogenous onlay bone grafts vs. alveolar distraction osteogenesis for the correction of vertically deficient edentulous ridges: A 2-4-year prospective study on humans. Clinical Oral Implants Research, 18(4), 432-440.

- Cordaro, L., \& Terheyden, H. (2014). ITI treatment guide Augmentation Procedures in Implant Patients.

- Cordaro, Luca., Torsello, F., Morcavallo, S., \& di Torresanto, V. M. (2011). Effect of bovine bone and collagen membranes on healing of mandibular bone blocks: A prospective randomized controlled study. Clinical Oral Implants Research, 22(10), 1145-1150.

- $\quad$ Donos, N., Kostopoulos, L., \& Karring, T. (2002). Alveolar ridge augmentation using a resorbable copolymer membrane and autogenous bone grafts: An experimental study in the rat. Clinical Oral Implants Research, 13(2), 203-213.

- $\quad$ Dye, B., Thornton-Evans, G., Li, X., \& Iafolla, T. (2015). Dental caries and tooth loss in adults in the United States, 2011-2012. NCHS Data Brief, 197, 197.

- $\quad$ Elnayef, B., Porta, C., del Amo, F., Mordini, L., GargalloAlbiol, J., \& Hernández-Alfaro, F. (2018). The Fate of Lateral Ridge Augmentation: A Systematic Review and Meta-Analysis. The International Journal of Oral \& Maxillofacial Implants, 33(3), 622-635.

- $\quad$ Esen, A., Yıldırım, G., İnan, Ö., \& Dolanmaz, D. (2015). The use of autogenous mandibular bone block grafts for reconstruction of alveolar defects. Annals of Maxillofacial Surgery, 5(1), 71.

- Gielkens, P. f. ., Schortinghuis, J., \& de jong, J. . (2008). The Influence of Barrier Membranes on Autologus Bone Grafts. Journal of Dental Research, 87(11), 1048-1052.
- González-García, R., Monje, F., \& Moreno, C. (2011). Alveolar split osteotomy for the treatment of the severe narrow ridge maxillary atrophy: a modified technique. International Journal of Oral and Maxillofacial Surgery, 40(1), 57-64.

- Hämmerle, C. H. F., \& Lang, N. P. (2001). Single stage surgery combining transmucosal implant placement with guided bone regeneration and bioresorbable materials. Clinical Oral Implants Research, 12(1), 9-18.

- Johnson, K. (1969). A study of the dimensional changes occurring in the maxilla following tooth extraction. Australian Dental Journal, 14(4), 241-244.

- Lekholm, U., Gunne, J., Henry, P., Higuchi, K., Lindén, U., Bergström, C., \& van Steenberghe, D. (1999). Survival of the Brånemark implant in partially edentulous jaws: a 10-year prospective multicenter study. The International Journal of Oral \& Maxillofacial Implants, 14(5), 639-645.

- $\quad$ Levin, L., Nitzan, D., \& Schwartz-arad, D. (2007). Success of Dental Implants Placed in Intraoral Block Bone Grafts. Periodontol, 78(1), 18-21.

- Maiorana, C., Beretta, M., Salina, S., \& Santoro, F. (2005). Reduction of autogenous bone graft resorption by means of bio-oss coverage: a prospective study. The International Journal of Periodontics \& Restorative Dentistry, 25(1), 19-25.

- Maiorana, C., Ferrario, S., Poli, P. P., \& Manfredini, M. (2020). Autogenous Chin Block Grafts in the Aesthetic Zone: A 20-Year Follow-Up Case Report. Case Reports in Dentistry, 2020.

- Mendoza-Azpur, G., de la Fuente, A., Chavez, E., Valdivia, E., \& Khouly, I. (2019). Horizontal ridge augmentation with guided bone regeneration using particulate xenogenic bone substitutes with or without autogenous block grafts: A randomized controlled trial. Clinical Implant Dentistry and Related Research, 21(4), 521-530.

- $\quad$ Miron, R. J., Hedbom, E., Saulacic, N., Zhang, Y., Sculean, A., Bosshardt, D. D., \& Buser, D. (2011). Osteogenic potential of autogenous bone grafts harvested with four different surgical techniques. Journal of Dental Research, 90(12), 1428-1433.

- Misch, C. (1997). Comparison of intraoral donor sites for onlay grafting prior to implant placement. Undefined, 12(6), 767-676.

- Misch, C. M. (1997). Comparison of intraoral donor sites for onlay grafting prior to implant placement. The International Journal of Oral \& Maxillofacial Implants, 12(6), 767-776. 
- Monje, A., Monje, F., Galindo-Moreno, P., MontaneroFernandez, J., Suarez, F., \& Wang, H.-L. (2014a). Microstructural and densiometric analysis of extra oral bone block grafts for maxillary horizontal bone augmentation: a comparison between calvarial bone and iliac crest. Clinical Oral Implants Research, 25(6), 659-664.

- Monje, A., Monje, F., Galindo-Moreno, P., MontaneroFernandez, J., Suarez, F., \& Wang, H. L. (2014b). Microstructural and densiometric analysis of extra oral bone block grafts for maxillary horizontal bone augmentation: A comparison between calvarial bone and iliac crest. Clinical Oral Implants Research, 25(6), 659-664.

- Monje, A., Monje, F., Hernández-Alfaro, F., GonzalezGarciá, R., Suárez-López Del Amo, F., Galindo-Moreno, P., Montanero-Fernández, J., \& Wang, H. La. (2015). Horizontal bone augmentation using Autogenous block grafts and particulate Xenograft in the severe atrophic maxillary anterior ridges: A cone-beam computerized tomography case Series. Journal of Oral Implantology, 41, 366-371.

- Moy, P. K., \& Aghaloo, T. (2019). Risk factors in bone augmentation procedures. Periodontology 2000, 81(1), 76-90.

- $\quad$ Pereira, C. C. S., Gealh, W. C., Meorin-Nogueira, L., Garcia-Júnior, I. R., \& Okamoto, R. (2014). Piezosurgery applied to implant dentistry: Clinical and biological aspects. In Journal of Oral Implantology (Vol. 40, Issue SPEC. ISSUE 1, pp. 401-408). Allen Press Inc.

- Pikos, M. A. (2005a). Mandibular block autografts for alveolar ridge augmentation. Atlas of the Oral and Maxillofacial Surgery Clinics of North America, 13(2), 91-107.

- $\quad$ Pikos, M. A. (2005b). Mandibular block autografts for alveolar ridge augmentation. In Atlas of the Oral and Maxillofacial Surgery Clinics of North America (Vol. 13, Issue 2,pp. 91-107).

- $\quad$ Rullo, R., Addabbo, F., Papaccio, G., D’Aquino, R., \& Festa, V. M. (2013). Piezoelectric device vs. conventional rotative instruments in impacted third molar surgery: Relationships between surgical difficulty and postoperative pain with histological evaluations. Journal of Cranio-Maxillofacial Surgery, 41(2).
- Sanz-Sánchez, I., Ortiz-Vigón, A., Sanz-Martín, I., Figuero, E., \& Sanz, M. (2015). Effectiveness of Lateral Bone Augmentation on the Alveolar Crest Dimension. Journal of Dental Research, 94(X), 128S-142S.

- $\quad$ Seibert, J. S., \& Cohen, D. W. (1987). Periodontal considerations in preparation for fixed and removable prosthodontics. Dental Clinics of North America, 31(3), $529-555$

- Sohn, D.-S., Ahn, M.-R., Lee, W.-H., Yeo, D.-S., \& Lim, S.-Y. (2007). Piezoelectric osteotomy for intraoral harvesting of bone blocks. The International Journal of Periodontics \& Restorative Dentistry, 27(2), 127-131.

- $\quad$ Tessier, P., Kawamoto, H., Matthews, D., Posnick, J., Raulo, Y., Tulasne, J. F., \& Wolfe, S. A. (2005). Autogenous bone grafts and bone substitutes - Tools and techniques: I. A 20,000-case experience in maxillofacial and craniofacial surgery. In Plastic and Reconstructive Surgery (Vol. 116, Issue 5 SUPPL.). Lippincott Williams and Wilkins.

- Von Arx, T., \& Buser, D. (2006). Horizontal ridge augmentation using autogenous block grafts and the guided bone regeneration technique with collagen membranes: A clinical study with 42 patients. Clinical Oral Implants Research, 17(4), 359-366.

- Wiltfang, J., Jätschmann, N., Hedderich, J., Neukam, F. W., Schlegel, K. A., \& Gierloff, M. (2014). Effect of deproteinized bovine bone matrix coverage on the resorption of iliac cortico-spongeous bone grafts - a prospective study of two cohorts. Clinical Oral Implants Research, 25(2), 127-132.

- Zaki, J., Alnawawy, M., Yussif, N., \& Elkhadem, A. (2017). The Effect of Membrane Coverage on the Resorption of Autogenous Intraoral Block Grafts IN HORIZONTAL RIDGE AUGMENTATION: A Systematic Review of Literature and Meta-Analysis: Inevitability or an Iatrogenic Vulnerability? Journal of Evidence-Based Dental Practice.

- Zhao, X., Zhu, B., Duan, Y., Wang, X., \& Li, D. (2018). The Effect of Smoking Behavior on Alveolar Bone Marrow Mesenchymal Stem Cells of Clinical Implant Patient. BioMed Research International, 2018. 